\title{
Cardiotoxicity and Chemotherapy-The Role of Precision Medicine
}

\author{
Thyla Viswanathan ${ }^{1}$, Chim C. Lang ${ }^{2,3}$, Russell D. Petty ${ }^{2,4}$ and Mark A. Baxter ${ }^{2,4, *}$ \\ 1 Dundee School of Medicine, Ninewells Hospital, University of Dundee, Dundee DD2 1SY, UK; \\ t.viswanathan@dundee.ac.uk \\ 2 Division of Molecular and Clinical Medicine, School of Medicine, University of Dundee, Dundee DD2 1SY, UK; \\ c.c.lang@dundee.ac.uk (C.C.L.); r.petty@dundee.ac.uk (R.D.P.) \\ 3 UKM Medical Molecular Biology Institute (UMBI), Jalan Yaacob Latif, Cheras, Kuala Lumpur 56000, Malaysia \\ 4 Tayside Cancer Centre, Ninewells Hospital and Medical School, NHS Tayside, Dundee DD2 1SY, UK \\ * Correspondence: m.z.baxter@dundee.ac.uk; Tel.: +44-1382-601111
}

check for updates

Citation: Viswanathan, T.;

Lang, C.C.; Petty, R.D.;

Baxter, M.A. Cardiotoxicity and Chemotherapy-The Role of Precision Medicine. Diseases 2021, 9 , 90. https://doi.org/10.3390/ diseases 9040090

Academic Editor: Kazuyuki Kitatani

Received: 30 August 2021

Accepted: 28 November 2021

Published: 8 December 2021

Publisher's Note: MDPI stays neutral with regard to jurisdictional claims in published maps and institutional affiliations.

Copyright: (c) 2021 by the authors. Licensee MDPI, Basel, Switzerland. This article is an open access article distributed under the terms and conditions of the Creative Commons Attribution (CC BY) license (https:/ / creativecommons.org/licenses/by/ $4.0 /)$.

\begin{abstract}
Cancer and cardiovascular disease are the leading causes of death in the United Kingdom. Many systemic anticancer treatments are associated with short- and long-term cardiotoxicity. With improving cancer survival and an ageing population, identifying those patients at the greatest risk of cardiotoxicity from their cancer treatment is becoming a research priority and has led to a new subspecialty: cardio-oncology. In this concise review article, we discuss cardiotoxicity and systemic anticancer therapy, with a focus on chemotherapy. We also discuss the challenge of identifying those at risk and the role of precision medicine as we strive for a personalised approach to this clinical scenario.
\end{abstract}

Keywords: cardiotoxicity; cardio-oncology; heart failure; cancer therapy; precision medicine; pharmacogenetics

\section{Introduction}

Survival for patients with cancer has increased in recent decades; doubling in the United Kingdom (UK) in the past forty years [1]. This improvement has, in part, been driven by the development of novel systemic anticancer therapies (including immune checkpoint inhibitors (ICIs) and targeted therapies) and a focus on biomarker-directed therapy [2].

Despite this improvement in outcomes, cancer, alongside cardiovascular disease, remains one of the leading causes of death in the UK [3]. With an ageing adult cancer population [4], who often have features of frailty and several comorbidities [5], the interaction between systemic anticancer therapy (SACT) and cardiovascular disease is an important consideration. Additionally, for those clinicians treating children and adolescents with cancer, reducing the risk of long-term cardiovascular consequences is vital.

The backbone of systemic management for many cancers, both in the paediatric, adolescent, and adult populations, remains chemotherapy [6]. Several chemotherapy agents, in particular anthracyclines, as well as some novel therapies, are associated with acute and delayed cardiotoxicity [6,7]. This can result in significant morbidity and mortality. For example, in the setting of paediatric cancers, survivors are $15 \times$ and $7 \times$ more likely to develop heart failure and die of cardiovascular disease, respectively, than their noncancer peers [8,9]. In those who develop cardiac dysfunction, prognosis is poor; a $24 \%$ 10-year mortality [10]. This has led to the development of a new field of interest in cardiology, cardio-oncology, which focuses on the detection, monitoring, and treatment of cardiovascular diseases occurring as a result of chemotherapy as well as radiotherapy [11].

At present, clinicians treating adult patients with cancer are unable to accurately identify those at an increased risk of chemotherapy-induced cardiotoxicity and cardiovascular complications. This can result in undertreatment or the premature cessation of treatment, particularly in older adults [12]. The challenge is underlined by the lack of consensus on 
what constitutes a diagnosis of cardiotoxicity, the heterogeneity of the treated population in clinical trials, and the absence of information on older adults [13].

Shared decision making with a patient is essential; the use of baseline left ventricular (LV) function and electrocardiograms, and the clinician's assessment of age and frailty, coupled to patient discussion, are the main drivers of treatment decisions [14]. The identification of a biomarker for those who are at risk of developing treatment-induced cardiotoxicity would enable a precision-medicine (utilising an individual's genetics, demographics, or tissue to prevent, diagnose, or treat) personalised approach to therapy-not only in terms of immediate treatment, but also in the approach to longitudinal monitoring and management.

In this concise review article, we will review treatment-induced cardiotoxicity in adult patients with cancer, with a focus on chemotherapeutics. We will also discuss the potential future role of precision medicine in identifying those at risk of developing cardiotoxicity.

\section{Chemotherapy-Induced Cardiotoxicity}

Several definitions of cardiotoxicity exist [15]. The most commonly referenced definition of cardiotoxicity is reduced LV function or failure [16]. However, cardiotoxicity in relation to anticancer therapy can also be broadly defined as any damage inflicted on the heart (functional or structural) from cancer treatments, including SACT and radiotherapy [17]. This can include a spectrum of conditions, including cardiac dysfunction, and effects beyond dysfunction, such as arrhythmias, hypertension, and thromboembolic events. Damage can be thought of as reversible or irreversible [18], although this classification has limitations, as certain anticancer therapies can cause both. The exact scale of this issue is not accurately documented; however, it is estimated that approximately $50 \%$ of patients may develop related cardiovascular events up to twenty years after initial SACT treatment [19].

Several classes of chemotherapy are associated with an increased risk of cardiotoxicity (Table 1). These include anthracyclines, antimetabolites, alkylating agents, vinca alkaloids, and taxanes. Each class of chemotherapy has a different mechanism of action (Figure 1) and, as such, produces a variety of cardiotoxic effects.

Table 1. Selected chemotherapy agents according to the class of drug and their associated cardiotoxic effects.

\begin{tabular}{ccl}
\hline Class & Example Drug & \multicolumn{1}{c}{ Cardiotoxic Effect } \\
\hline Anthracycline & $\begin{array}{c}\text { Doxorubicin } \\
\text { Epirubicin }\end{array}$ & $\begin{array}{l}\text { Impaired LV function due to irreversible } \\
\text { damage to cardiomyocytes [20]. }\end{array}$ \\
\hline Antimetabolite & $\begin{array}{c}\text { Capecitabine } \\
\text { 5-fluorouracil }\end{array}$ & $\begin{array}{l}\text { Arterial vasospasm, myocardial } \\
\text { ischaemia, and thrombosis [21]. }\end{array}$ \\
\hline Alkylating agent & Cisplatin & Thrombosis, arterial hypertension [22]. \\
\cline { 2 - 3 } & Cyclophosphamide & $\begin{array}{l}\text { Myocardial ischaemia, endothelial cell } \\
\text { injury [23]. }\end{array}$ \\
\hline Vinca alkaloid & Vincristine & $\begin{array}{l}\text { Myocardial ischaemia, arterial } \\
\text { hypertension [24]. }\end{array}$ \\
\hline \multirow{2}{*}{ Taxane } & Vinblastine & $\begin{array}{l}\text { Myocardial ischaemia, QT prolongation, } \\
\text { and bradycardia [25]. }\end{array}$ \\
\hline
\end{tabular}




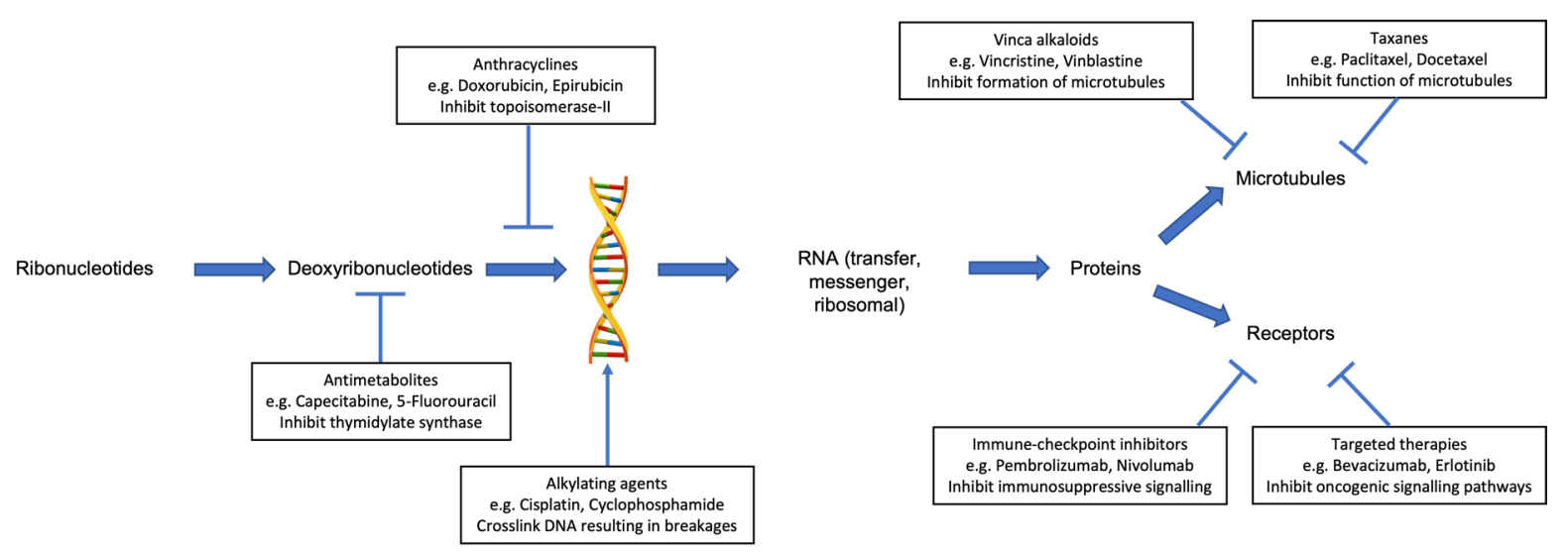

Figure 1. Mechanism of anticancer activity for selected individual classes of systemic anticancer therapy, which are associated with cardiotoxicity.

\subsection{Cardiac Dysfunction}

Cardiac dysfunction is defined by the Cardiac Review and Evaluation Committee supervising trastuzumab clinical trials [26] as: "(1) A decrease in the cardiac left ventricular ejection fraction (LVEF) that was either global or more severe in the septum; (2) Symptoms of congestive heart failure (CHF); (3) Associated signs of CHF, including, but not limited to S3 gallop, tachycardia, or both; and (4) A decline in the LVEF of at least $5 \%$ to less than $55 \%$, with accompanying signs or symptoms of CHF, or a decline in the LVEF of at least $10 \%$ to below $55 \%$, without accompanying signs or symptoms".

Several risk factors predispose to cardiac dysfunction [27,28]. These include age, pre-existing cardiovascular disease, combination anticancer therapy (in particular with anti-HER2 targeted therapy, such as trastuzumab), prior cardiac exposure to irradiation, the female sex, and genetics. For older adults, age-related cardiac deconditioning, comorbidities, ischaemia, polypharmacy, and cardiac cell senescence will also all contribute to risk.

Anthracyclines are the most recognised group of chemotherapy agents to cause cardiac dysfunction - with a $5 \times$ greater risk than non-anthracyclines [20]. They are used across a range of tumour histologies, settings, and age of patient. Anthracycline agents include doxorubicin (Adriamycin), daunorubicin, epirubicin, and idarubicin. Their anticancer mechanisms of action involve the inhibition of DNA and RNA synthesis, inducing cell membrane damage, the inhibition of topoisomerase II, and the generation of iron-mediated free oxygen radicals [29].

During this process, and their metabolism via mitochondrial NADH dehydrogenase, they also cause injury to cardiomyocytes via lipid peroxidation and the generation of reactive oxygen species (ROS) [30]. The formation of anthracycline-iron complexes may also catalyse a Fenton reaction, further increasing ROS production [31]. Together, these mechanisms induce DNA damage with resultant apoptosis [32]. Importantly, the cardiomyocyte dependence on oxidative metabolism may explain their greater susceptibility to anthracyclines.

Anthracyclines result in irreversible cardiac damage; however, because of cardiac reserves and compensatory mechanisms, e.g., myocyte hypertrophy, the damage often does not become clinically apparent for months or years following administration [33]. The impact is age- and dose-dependent, with children and those aged $>65$ years at increased risk, and the risk rising exponentially above $300 \mathrm{mg} / \mathrm{m}^{2}$ of doxorubicin, or $550 \mathrm{mg} / \mathrm{m}^{2}$ of epirubicin [34] (Table 2). 
Table 2. Incidence of left ventricular (LV) dysfunction associated with selected chemotherapy agents.

\begin{tabular}{|c|c|}
\hline Chemotherapy Agent & Incidence of LV Dysfunction \\
\hline \multicolumn{2}{|l|}{ Anthracyclines } \\
\hline \multicolumn{2}{|l|}{ Doxorubicin [34] } \\
\hline $400 \mathrm{mg} / \mathrm{m}^{2}$ & $3-5 \%$ \\
\hline $550 \mathrm{mg} / \mathrm{m}^{2}$ & $7-26 \%$ \\
\hline $700 \mathrm{mg} / \mathrm{m}^{2}$ & $18-48 \%$ \\
\hline \multicolumn{2}{|l|}{ Epirubicin [35] } \\
\hline$>900 \mathrm{mg} / \mathrm{m}^{2}$ & $0.9-11.4 \%$ \\
\hline \multicolumn{2}{|l|}{ Alkylating agents } \\
\hline Cyclophosphamide [36] & $7-28 \%$ \\
\hline \multicolumn{2}{|l|}{ Ifosfamide [37] } \\
\hline$<10 \mathrm{~g} / \mathrm{m}^{2}$ & $0.5 \%$ \\
\hline $10-18 \mathrm{~g} / \mathrm{m}^{2}$ & $17 \%$ \\
\hline \multicolumn{2}{|l|}{ Antimicrotubule agents } \\
\hline Docetaxel [38] & $2.3-8 \%$ \\
\hline Paclitaxel [25] & $1-10 \%$ \\
\hline
\end{tabular}

\subsection{Other Cardiac Implications}

An additional group of cardiotoxicities can include arrhythmia, ischaemia, and hypertension. The heart rhythm is reliant on the electrolyte balance, which can be disrupted temporarily, either because of the administration of the chemotherapy agents themselves, or because of subsequent systemic effects, for example, the platinum-induced disruption of renal electrolyte excretion [39]. Indirectly, the side effects of chemotherapy, such as vomiting and diarrhea, can also induce reversible electrolyte imbalance. This, coupled with the use of certain antiemetics, can increase the risk of cardiac rhythm changes, such as QT-prolongation. Rhythm changes can also be caused by structural changes to the heart, such as those induced by anthracyclines [40].

One of the most commonly used groups of chemotherapy agents in solid tumours are the antimetabolites, such as capecitabine and 5-fluorouracil. Both of these agents are associated with coronary artery vasospasm, which presents as atypical chest pain, angina upon exertion or rest, and acute coronary syndromes, including myocardial infarction [21]. Despite underlying cardiovascular disease being associated with an increased risk, this phenomenon is most commonly observed in those with normal coronary arteries, with an incidence between 1-18\% [41].

Patients with cancer are at an increased risk of thrombus [42], both venous and arterial. This hypercoagulable state is further increased by the administration of chemotherapy [43]. The best example of this is cisplatin, which has been reported to have a thromboembolic incidence rate between 6.6-18.1\% [44,45]. Although the majority of these thrombotic events are peripheral and venous, pulmonary emboli are common and can result in increased pulmonary pressures and right-sided heart failure. In addition, increased arterial embolic events can result in myocardial infarction as well as systemic hypertension.

\section{Other Anticancer Therapies}

As the understanding of the biology of cancer has developed, specific drivers of tumour growth have been identified. Several of these drivers can now be targeted by drugs in clinical use with significant improvements in disease control. An example is the monoclonal antibody, trastuzumab (Herceptin), in HER2-amplified breast and gastric cancer. Furthermore, in the past decade, the treatment paradigm of many cancers has been altered by the emergence of ICIs, which utilise the host immune system to produce an anti-tumoural effect. Both classes of drugs can have off-target cardiac toxicity, which is often challenging to detect, and both have different management approaches. 
This is an emerging clinical challenge as, in several tumour groups, there are now multiple combination regimens, including chemotherapy, targeted therapy, and an ICI, making the monitoring and selection of the appropriate management of cardiotoxicity difficult [46].

\subsection{Targeted Therapies}

The most wellrecognised targeted therapy is trastuzumab (Herceptin). This is an IgG1 monoclonal antibody that binds to the extracellular domain of the HER2/ERBB2 receptor, thus inhibiting dimerization and preventing the downstream intracellular signalling pathways. HER2 is amplified in approximately $15-30 \%$ of breast cancers, and in $10-30 \%$ of gastroesophageal cancers, and these are the main tumour groups in which anti-HER2 therapy is used [47].

Cardiac tissue is also known to express HER2 receptors, which have a protective function in the cardiomyocyte. Trastuzumab reversibly inhibits this function, with subsequent systolic impairment [48]. The rates of systolic dysfunction for single-agent trastuzumab are 3-7\% [49], with a higher incidence in combination regimes; for example, in anthracyclinetrastuzumab regimes, an incidence of up to $36 \%$ has been reported [50]. This observation is supported by preclinical work, which demonstrates increased sensitivity to the anthracycline cardiotoxic effects on the interruption of HER2 signalling [51]. Several other HER2-targeting therapies are in clinical use, including pertuzumab, lapatinib, neratinib, and trastuzumab emastine (TDM-1), with neratinib the only one that does not appear to cause cardiotoxicity.

Other selected targeted agents associated with cardiotoxicity include bevacizumab (used primarily in ovarian and colorectal cancers) and sunitinib (used in renal cell cancer). Bevacizumab is a humanised monoclonal antibody that binds to the ligand of vascular endothelial growth factor A (VEGF-A), inhibiting its binding to endothelial cells. It is primarily associated with hypertension, with an incidence of 4-35\% [52]. This hypertension is believed to drive the $2-4 \%$ incidence of congestive heart failure [53]. Bevacizumab is also associated with arterial thromboembolic events, including myocardial infarction [54]. This is likely due to a reduction in the anti-inflammatory effects of chronic VEGF exposure, the inhibition of endothelial repair, and a reduction in the levels of nitric oxide and prostacyclin [52].

Sunitinib is a pan-tyrosine kinase inhibitor that binds to several receptors, including VEGF receptors 1-3; stem-cell-factor receptor (c-KIT); the platelet-derived growth factor receptors (PDGFR), alpha and beta; colony-stimulating-factor 1 receptor; FLT3 kinase; and RET kinase. The cardiotoxicity (hypertension and/or LVEF decline) induced by the inhibition of these receptors is an off-target effect, with an incidence of up to $15 \%$ [55]. VEGFR inhibition reduces the heart-capillary density and KIT plays a role in the endothelial cell mobilisation to sites of myocardial injury [56]. Patients on tyrosine kinase inhibitors can remain on therapy until disease progression, which can be for several years $[57,58]$. As such, close monitoring for cardiac toxicity is an important part of the clinical assessment and pathway.

\subsection{Immune-Checkpoint Inhibitors}

ICIs have altered the treatment paradigm of several tumour groups in recent years and are now licenced for a range of histological subtypes across several settings [59-61]. However, similar to other antineoplastic agents, they are associated with a risk of cardiotoxicity—albeit with a distinct mechanism from chemotherapy and targeted therapies [62].

The most prominent ICI targets are the host immune suppression proteins, cytotoxicT-lymphocyte-associated antigen 4 (CTLA4), and programmed cell death 1 (PD-1), along with its ligand, PD-L1. As such, the driving mechanism of the cardiotoxicity of these agents is primarily immune-mediated. The rates of immune-mediated cardiotoxicity (including myocarditis, pericardial disease, conduction abnormalities, and cardiomyopathy) are 
estimated between 0.1 and $3.2 \%[63,64]$ and appear similar for each individual ICI. However, combination therapy is associated with a higher risk $[62,65]$.

Human myocytes have been shown to express both PD-L1 and PD-1 [66], and mice deficient in CTLA-4 and PD-1 are at increased risk of acute myocarditis [67]. There is, therefore, mechanistic support underlying the immune-mediated cardiotoxicity observed. Early identification and treatment with high-dose steroids are essential to preventing arrhythmia, long-term cardiac damage, or death [64,68]. This, however, is made more challenging as the cardiac parameters, including troponin, are not often routinely evaluated in oncology real-world clinical or trial settings. As such, the aforementioned incidence rates may be a significant underestimate of the true rates.

At present, there is no way to identify those at risk. However, it is recognised that patients receiving combination therapy (anti-CTLA4 with anti-PD1/anti-PD-L1), or those with a pre-existing autoimmune disease, are at an increased risk of further immune-related events [69].

\section{Management of Patients Receiving Cardiotoxic Agents}

Both the European Society of Cardiology (ESC) and the European Society of Medical Oncology (ESMO) have produced guidelines for the management of patients receiving a potentially cardiotoxic agent $[13,27]$. Before the initiation of a potentially cardiotoxic agent, all patients should undergo a thorough cardiovascular assessment, with a specific focus on a history suggestive of ischaemic disease or impaired cardiac function. Blood pressure should be measured and, in those patients receiving multitargeted agents, this, as well as any comorbidities, should be robustly managed before and during therapy. Baseline investigations should include an electrocardiogram, an assessment of the left ventricular ejection fraction, and a measurement of the cardiac biomarkers (troponin and BNP, or NT ProBNP). Consideration should be given to performing a 6-min walk test.

For patients deemed to be at high risk of cardiotoxicity, a prophylactic cardioprotective regime should be initiated: an angiotensin-converting enzyme inhibitor (ACEi)/angiotensin II receptor blocker (ARB) and a beta-blocker [70]. For those receiving an anthracycline, the use of prophylactic dexrazoxane has been shown to reduce the rates of heart failure [71]. Patients with pre-existing cardiac dysfunction should be referred for specialist cardiology review before the initiation of therapy. Careful consideration should be taken of the risk-benefit balance of the treatment and, where possible, modifications to the regime should be made.

While on treatment, for asymptomatic patients, the functional status and cardiac imaging (echocardiogram or MUGA scan) should be performed every 3 months. In those who become symptomatic, imaging should be performed to assess the left ventricular function and the anticancer agent should be interrupted while the investigation is performed.

For low-risk patients who develop asymptomatic or symptomatic cardiac dysfunction, management is dependent on the causative agent. Broadly, targeted therapy and ICImediated dysfunction are reversible upon interruption of the drug. In the acute setting, immune-mediated cardiac toxicity (e.g., myocarditis/pericarditis) should be managed with steroids [72]. For those with more prolonged dysfunction, the use of an ACEi/ARB alongside a beta-blocker is recommended [73]. The outcomes are similar to the general heart failure population, and combination therapy appears more effective than the use of ACEi/ARB or a beta-blocker alone [73,74]. There is no role at present for ACEi in the prevention of the development of cardiac dysfunction [27].

Following the completion of therapy, long-term surveillance should be considered for all patients. This is particularly important for those patients who developed cardiotoxicity and are receiving cardioprotective medication. For those who have received anthracyclines, lifelong surveillance should be undertaken, as is recommended for survivors of childhood cancer [75]. 


\section{The Role of Precision Medicine}

Although several risk factors have been identified, the mechanisms and predictors of chemotherapy-induced cardiotoxicity are poorly understood. It is recognised that early diagnosis and the treatment of cardiotoxicity improves outcomes [73,74]. There are currently no accurate and validated biomarker models to predict which patients are at the highest risk. We are, therefore, unable to prevent cardiotoxicity from occurring or personalise treatment at a precision level. This issue is compounded by the lack of a unified definition of "cardiotoxicity" [76]. The majority of current decisions are made on heuristic learning integrating available biomarkers, including patient assessment, planned treatment, patient samples (e.g., serum), and imaging results.

The identification of a future predictive biomarker will likely necessitate a consideration of the above, as well as the integration of genomic studies (Figure 2). This will ultimately require a translational approach from bench to bedside, incorporating patient samples (including serum and tissue) and pharmacogenomics, with longitudinal clinical outcomes and cardiac imaging data.

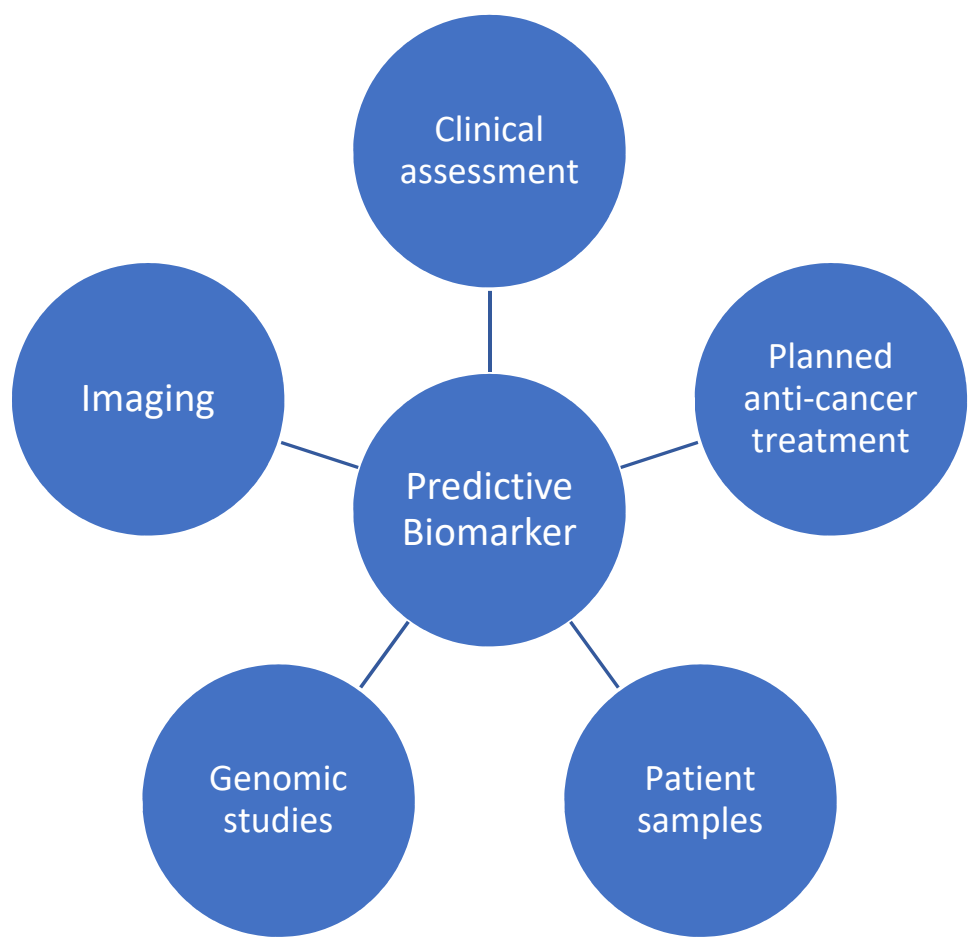

Figure 2. Contributing factors to a future predictive biomarker for anticancer therapy cardiotoxicity.

At present, a risk assessment requires that a thorough baseline individualised patient history and an examination be undertaken, and the risk factors for cardiovascular disease (and, thus, treatment-induced cardiotoxicity), such as obesity, diabetes, hypertension, and prior cancer treatment, are to be identified, and managed or modified. Clinicians also require knowledge of the baseline cardiac rhythm and function, coupled to the baseline serum markers, such as troponin. Importantly, early changes in troponin have been shown to predict cardiotoxicity in patients with breast cancer and treated with an anthracycline [77]. Cardiac function is assessed primarily using an echocardiogram (ECHO), as per ASCO guidelines [78]. Baseline LVEF does not appear to independently predict who will develop cardiotoxicity [79]. However, the exclusion of patients with reduced LVEF from clinical trials means that there is a reluctance among clinicians to prescribe potentially cardiotoxic regimes to this patient group. The emerging research interest is the potential predictive ability of global longitudinal strain (GLS) and global circumferential strain (GCS), both of which appear to identify those at the greatest risk for the development of cardiotoxicity $[80,81]$. 
Together, these factors form a biomarker-based risk stratification for the patient and clinician and will influence the intended anticancer regime and dosing schedule. In the future, patient genetics may also be incorporated, and this influence is a growing current research interest. Genetic changes, in particular, single nucleotide polymorphisms (SNPs) that influence drug absorption, intracellular transport, metabolism, and elimination may play an important role [82]. Recently, genome-wide association studies (GWAS), using a top-down approach, have identified novel genetic variants and their related genes, which are statistically significantly related to chemotherapy-induced cardiotoxicity [83]. Several meta-analyses have been performed. A meta-analysis of 41 studies, including 9183 patients, detected a significantly increased risk associated with six variants: CYBA rs4673, RAC2 rs13058338, CYP3A5 rs776746, ABCC1 rs45511401, ABCC2 rs8187710, and HER2-Ile655Val rs1136201 [83], while another exploring 40 studies (35 using a candidate gene approach and 5 GWAS), with 10,320 patients, identified CELF rs1786814, RARG rs2229774, SLC28A3 rs7853758, and UGT1A6 rs17863783 [84].

Another reported candidate is the SNP, rs246221, encoding a heterozygous carrier of the ABCC1 gene, which plays a role in cellular drug efflux. This SNP was associated with a reduction in the LVEF of $>10 \%$, compared to homozygous carriers in patients treated with epirubicin for early breast cancer [85].

Despite the identification of the aforementioned potential candidate genetic changes, the data remains inconsistent and the targets require validation. As such, larger genetic polymorphism studies are required to identify and further elucidate the potential mechanisms of cardiotoxicity.

In Dundee, we have access to a large biorepository, including the Genetics of the Scottish Health Research Register (GoSHARE), and the Genetics of Diabetes Audit and Research (GoDARTS) [86]. These resources enable access to over 200,000 individual patient blood samples, in addition to paired SACT and longitudinal LVEF data, among other variables. This provides a unique platform to investigate the role of specific baseline biomarkers on long-term cardiovascular outcomes. This will be a focus of ongoing research in our unit.

In addition to retrospective genetic analysis, the advent of human-induced pluripotent stem cell models will provide an in vitro system to explore the effect of genomic findings. This will drive hypotheses relating to the underlying mechanisms driving cardiotoxicity and will facilitate the development and investigation of novel strategies to mitigate cardiovascular toxicity $[87,88]$.

\section{Conclusions}

Systemic anticancer therapy is associated with cardiotoxicity through various mechanisms. This has traditionally been associated with chemotherapy, but novel therapies can also impact cardiac function. As the adult cancer population increases in age and, therefore, the predisposition to cardiovascular disease, the effect of SACT on the heart, both in the short- and long-term, takes on more importance. Accurately identifying those who will develop cardiotoxicity is not currently possible. To address this need, a translational bench-to-bedside approach is essential.

Author Contributions: Conceptualization, T.V., C.C.L., R.D.P., M.A.B.; writing-original draft preparation, T.V. and M.A.B.; writing-review and editing, T.V., C.C.L., R.D.P., M.A.B.; visualization, T.V. and M.A.B. All authors have read and agreed to the published version of the manuscript.

Funding: M.A.B. is a Clinical Academic Fellow funded by the Scottish Chief Scientist Office. C.C.L. is a Distinguished Professor at the UKM Medical Molecular Biology Institute (UMBI).

Institutional Review Board Statement: Not applicable.

Informed Consent Statement: Not applicable. 
Conflicts of Interest: M.A.B. has undertaken speaking roles for Ipsen. R.D.P. has undertaken speaking, consulting, and advisory roles for Eli Lilly, BMS, Pfizer, Sanofi, and Servier, and has received research funding (not related to the work in this manuscript) from Astra Zeneca, Roche, MSD, Merck serrano, Eli Lilly, Five Prime Therapeutics, Clovis, Boston Biomedical, and Janssen. T.V. and C.C.L. have no conflict of interest to declare.

$\begin{array}{ll}\text { Abbreviations } \\ \text { BNP } & \text { B-natriuretic protein } \\ \text { CHF } & \text { congestive heart failure } \\ \text { c-KIT } & \text { stem-cell-factor receptor } \\ \text { CTLA-4 } & \text { cytotoxic T lymphocyte-associated antigen-4 } \\ \text { ICI } & \text { immune checkpoint inhibitor } \\ \text { LV } & \text { left ventricular } \\ \text { LVEF } & \text { left ventricular ejection fraction } \\ \text { PD-1 } & \text { programmed cell death protein 1 } \\ \text { PDGFR } & \text { platelet derived growth factor receptor } \\ \text { SACT } & \text { systemic anticancer therapy } \\ \text { SNP } & \text { single nucleotide polymorphism } \\ \text { UK } & \text { United Kingdom } \\ \text { VEGF } & \text { vascular endothelial growth factor. }\end{array}$

\section{References}

1. CRUK. Cancer Survival Statistics. Available online: https://www.cancerresearchuk.org/health-professional/cancer-statistics/ survival\#heading-Zero (accessed on 6 July 2021).

2. $\quad$ D'Avó Luís, A.B.; Seo, M.K. Has the development of cancer biomarkers to guide treatment improved health outcomes? Eur. J. Health Econ. 2021, 22, 789-810. [CrossRef]

3. Statistics, O.f.N. Deaths. Available online: https://www.ons.gov.uk/peoplepopulationandcommunity/birthsdeathsandmarriages/ deaths (accessed on 30 August 2021).

4. Pilleron, S.; Soto-Perez-De-Celis, E.; Vignat, J.; Ferlay, J.; Soerjomataram, I.; Bray, F.; Sarfati, D. Estimated global cancer incidence in the oldest adults in 2018 and projections to 2050. Int. J. Cancer 2020, 3, 601-608. [CrossRef] [PubMed]

5. Handforth, C.; Clegg, A.; Young, C.; Simpkins, S.; Seymour, M.T.; Selby, P.J.; Young, J. The prevalence and outcomes of frailty in older cancer patients: A systematic review. Ann. Oncol. 2015, 26, 1091-1101. [CrossRef] [PubMed]

6. Volkova, M.; Russell, R., 3rd. Anthracycline cardiotoxicity: Prevalence, pathogenesis and treatment. Curr. Cardiol. Rev. 2011, 7, 214-220. [CrossRef] [PubMed]

7. Palaskas, N.; Lopez-Mattei, J.; Durand, J.B.; Iliescu, C.; Deswal, A. Immune Checkpoint Inhibitor Myocarditis: Pathophysiological Characteristics, Diagnosis, and Treatment. J. Am. Heart Assoc. 2020, 9, e013757. [CrossRef] [PubMed]

8. Lu, Z.; Fang, Y.; Liu, C.; Zhang, X.; Xin, X.; He, Y.; Cao, Y.; Jiao, X.; Sun, T.; Pang, Y.; et al. Early Interdisciplinary Supportive Care in Patients With Previously Untreated Metastatic Esophagogastric Cancer: A Phase III Randomized Controlled Trial. J. Clin. Oncol. 2021, 39, 748-756. [CrossRef]

9. Armstrong, G.T.; Liu, Q.; Yasui, Y.; Neglia, J.P.; Leisenring, W.; Robison, L.L.; Mertens, A.C. Late mortality among 5-year survivors of childhood cancer: A summary from the Childhood Cancer Survivor Study. J. Clin. Oncol. 2009, 27, 2328-2338. [CrossRef] [PubMed]

10. Fornaro, A.; Olivotto, I.; Rigacci, L.; Ciaccheri, M.; Tomberli, B.; Ferrantini, C.; Coppini, R.; Girolami, F.; Mazzarotto, F.; Chiostri, M.; et al. Comparison of long-term outcome in anthracycline-related versus idiopathic dilated cardiomyopathy: A single centre experience. Eur. J. Heart Fail. 2018, 20, 898-906. [CrossRef] [PubMed]

11. Kostakou, P.M.; Kouris, N.T.; Kostopoulos, V.S.; Damaskos, D.S.; Olympios, C.D. Cardio-oncology: A new and developing sector of research and therapy in the field of cardiology. Heart Fail. Rev. 2019, 24, 91-100. [CrossRef] [PubMed]

12. Fourcadier, E.; Trétarre, B.; Gras-Aygon, C.; Ecarnot, F.; Daurès, J.-P.; Bessaoud, F. Under-treatment of elderly patients with ovarian cancer: A population based study. BMC Cancer 2015, 15, 937. [CrossRef]

13. Curigliano, G.; Cardinale, D.; Suter, T.; Plataniotis, G.; de Azambuja, E.; Sandri, M.T.; Criscitiello, C.; Goldhirsch, A.; Cipolla, C.; Roila, F. Cardiovascular toxicity induced by chemotherapy, targeted agents and radiotherapy: ESMO Clinical Practice Guidelines. Ann. Oncol. 2012, 23 (Suppl. 7), vii155-vii166. [CrossRef]

14. Hull, S.C.; Soufer, A.; Spatz, E.S.; Baldassarre, L.A. Rationale and proposed framework for shared decision making in cardiooncology. Cardio-Oncology 2021, 7, 30. [CrossRef] [PubMed]

15. López-Sendón, J.; Álvarez-Ortega, C.; Zamora Auñon, P.; Buño Soto, A.; Lyon, A.R.; Farmakis, D.; Cardinale, D.; Canales Albendea, M.; Feliu Batlle, J.; Rodríguez Rodríguez, I.; et al. Classification, prevalence, and outcomes of anticancer therapyinduced cardiotoxicity: The CARDIOTOX registry. Eur. Heart J. 2020, 41, 1720-1729. [CrossRef] [PubMed]

16. Pardo Sanz, A.; Zamorano, J.L. 'Cardiotoxicity': Time to define new targets? Eur. Heart J. 2020, 41, 1730-1732. [CrossRef] 
17. Florescu, M.; Cinteza, M.; Vinereanu, D. Chemotherapy-induced Cardiotoxicity. Maedica 2013, 8, 59-67. [PubMed]

18. Suter, T.M.; Ewer, M.S. Cancer drugs and the heart: Importance and management. Eur. Heart J. 2013, 34, 1102-1111. [CrossRef] [PubMed]

19. Soujeri, B.; Singh, J.; Chew, S.; Hawkey, S.; Ferguson, M.; Lang, C.C. 23 Surveillance and Incidence of Chemotherapy-Induced Cardiotoxicity in Breast Cancer: A Long Term Observational Study. Heart 2016, 102 (Suppl. 6), A14. [CrossRef]

20. Smith, L.A.; Cornelius, V.R.; Plummer, C.J.; Levitt, G.; Verrill, M.; Canney, P.; Jones, A. Cardiotoxicity of anthracycline agents for the treatment of cancer: Systematic review and meta-analysis of randomised controlled trials. BMC Cancer 2010, $10,337$. [CrossRef]

21. Sara, J.D.; Kaur, J.; Khodadadi, R.; Rehman, M.; Lobo, R.; Chakrabarti, S.; Herrmann, J.; Lerman, A.; Grothey, A. 5-fluorouracil and cardiotoxicity: A review. Ther. Adv. Med. Oncol. 2018, 10, 1758835918780140. [CrossRef] [PubMed]

22. Jafri, M.; Protheroe, A. Cisplatin-associated thrombosis. Anti-Cancer Drugs 2008, 19, 927-929. [CrossRef]

23. Morandi, P.; Ruffini, P.A.; Benvenuto, G.M.; Raimondi, R.; Fosser, V. Cardiac toxicity of high-dose chemotherapy. Bone Marrow Transpl. 2005, 35, 323-334. [CrossRef]

24. Herradón, E.; González, C.; González, A.; Uranga, J.A.; López-Miranda, V. Cardiovascular Toxicity Induced by Chronic Vincristine Treatment. Front. Pharmacol. 2021, 12, 692970. [CrossRef]

25. Osman, M.; Elkady, M. A Prospective Study to Evaluate the Effect of Paclitaxel on Cardiac Ejection Fraction. Breast Care 2017, 12, 255-259. [CrossRef]

26. National Cancer Institute. Cancer Therapy Evaluation Program. 2012. Available online: http://ctep.cancer.gov/ protocoldevelopment/electronic_applications/docs/ctcv20_4e30e992.pdf (accessed on 30 August 2021).

27. Zamorano, J.L.; Lancellotti, P.; Rodriguez Muñoz, D.; Aboyans, V.; Asteggiano, R.; Galderisi, M.; Habib, G.; Lenihan, D.J.; Lip, G.Y.H.; Lyon, A.R.; et al. 2016 ESC Position Paper on cancer treatments and cardiovascular toxicity developed under the auspices of the ESC Committee for Practice Guidelines: The Task Force for cancer treatments and cardiovascular toxicity of the European Society of Cardiology (ESC). Eur. Heart J. 2016, 37, 2768-2801. [CrossRef]

28. Screever, E.M.; Meijers, W.C.; Moslehi, J.J. Age-Related Considerations in Cardio-Oncology. J. Cardiovasc. Pharmacol. Ther. 2021, 26, 103-113. [CrossRef] [PubMed]

29. Szuławska, A.; Czyz, M. Molecular mechanisms of anthracyclines action. Postepy Hig. Med. Dosw. 2006, 60, 78-100.

30. Davies, K.J.; Doroshow, J.H. Redox cycling of anthracyclines by cardiac mitochondria. I. Anthracycline radical formation by NADH dehydrogenase. J. Biol. Chem. 1986, 261, 3060-3067. [CrossRef]

31. Kotamraju, S.; Chitambar, C.R.; Kalivendi, S.V.; Joseph, J.; Kalyanaraman, B. Transferrin receptor-dependent iron uptake is responsible for doxorubicin-mediated apoptosis in endothelial cells: Role of oxidant-induced iron signaling in apoptosis. J. Biol. Chem. 2002, 277, 17179-17187. [CrossRef]

32. Kotamraju, S.; Konorev, E.A.; Joseph, J.; Kalyanaraman, B. Doxorubicin-induced apoptosis in endothelial cells and cardiomyocytes is ameliorated by nitrone spin traps and ebselen. Role of reactive oxygen and nitrogen species. J. Biol. Chem. 2000, 275, 33585-33592. [CrossRef]

33. Mann, D.L.; Bristow, M.R. Mechanisms and models in heart failure: The biomechanical model and beyond. Circulation 2005, 111, 2837-2849. [CrossRef]

34. Swain, S.M.; Whaley, F.S.; Ewer, M.S. Congestive heart failure in patients treated with doxorubicin: A retrospective analysis of three trials. Cancer 2003, 97, 2869-2879. [CrossRef] [PubMed]

35. Ryberg, M.; Nielsen, D.; Cortese, G.; Nielsen, G.; Skovsgaard, T.; Andersen, P.K. New insight into epirubicin cardiac toxicity: Competing risks analysis of 1097 breast cancer patients. J. Natl. Cancer Inst. 2008, 100, 1058-1067. [CrossRef] [PubMed]

36. Gottdiener, J.S.; Appelbaum, F.R.; Ferrans, V.J.; Deisseroth, A.; Ziegler, J. Cardiotoxicity associated with high-dose cyclophosphamide therapy. Arch. Intern. Med. 1981, 141, 758-763. [CrossRef] [PubMed]

37. Monsuez, J.J.; Charniot, J.C.; Vignat, N.; Artigou, J.Y. Cardiac side-effects of cancer chemotherapy. Int. J. Cardiol. 2010, 144, 3-15. [CrossRef] [PubMed]

38. Yeh, E.T.; Bickford, C.L. Cardiovascular complications of cancer therapy: Incidence, pathogenesis, diagnosis, and management. J. Am. Coll. Cardiol. 2009, 53, 2231-2247. [CrossRef]

39. Miller, R.P.; Tadagavadi, R.K.; Ramesh, G.; Reeves, W.B. Mechanisms of Cisplatin nephrotoxicity. Toxins 2010, 2, 2490-2518. [CrossRef]

40. Sawyer, D.B.; Peng, X.; Chen, B.; Pentassuglia, L.; Lim, C.C. Mechanisms of anthracycline cardiac injury: Can we identify strategies for cardioprotection? Prog. Cardiovasc. Dis. 2010, 53, 105-113. [CrossRef]

41. Van Cutsem, E.; Hoff, P.M.; Blum, J.L.; Abt, M.; Osterwalder, B. Incidence of cardiotoxicity with the oral fluoropyrimidine capecitabine is typical of that reported with 5-fluorouracil. Ann. Oncol. 2002, 13, 484-485. [CrossRef] [PubMed]

42. Trousseau, A. Phlegmasia alba dolens. In Lectures on Clinical Medicine; Hôtel-Dieu: Paris, France, 1872.

43. Khorana, A.A.; Dalal, M.; Lin, J.; Connolly, G.C. Incidence and predictors of venous thromboembolism (VTE) among ambulatory high-risk cancer patients undergoing chemotherapy in the United States. Cancer 2013, 119, 648-655. [CrossRef]

44. Moore, R.A.; Adel, N.; Riedel, E.; Bhutani, M.; Feldman, D.R.; Tabbara, N.E.; Soff, G.; Parameswaran, R.; Hassoun, H. High incidence of thromboembolic events in patients treated with cisplatin-based chemotherapy: A large retrospective analysis. J. Clin. Oncol. 2011, 29, 3466-3473. [CrossRef] 
45. Abdel-Razeq, H.; Mansour, A.; Abdulelah, H.; Al-Shwayat, A.; Makoseh, M.; Ibrahim, M.; Abunasser, M.; Rimawi, D.; Al-Rabaiah, A.; Alfar, R.; et al. Thromboembolic events in cancer patients on active treatment with cisplatin-based chemotherapy: Another look! Thromb. J. 2018, 16, 2. [CrossRef] [PubMed]

46. Xu, S.; Sharma, U.C.; Tuttle, C.; Pokharel, S. Immune Checkpoint Inhibitors: Cardiotoxicity in Pre-clinical Models and Clinical Studies. Front. Cardiovasc. Med. 2021, 8, 619650. [CrossRef] [PubMed]

47. Iqbal, N.; Iqbal, N. Human Epidermal Growth Factor Receptor 2 (HER2) in Cancers: Overexpression and Therapeutic Implications. Mol. Biol. Int. 2014, 2014, 852748. [CrossRef]

48. Sawyer, D.B.; Zuppinger, C.; Miller, T.A.; Eppenberger, H.M.; Suter, T.M. Modulation of anthracycline-induced myofibrillar disarray in rat ventricular myocytes by neuregulin-1beta and anti-erbB2: Potential mechanism for trastuzumab-induced cardiotoxicity. Circulation 2002, 105, 1551-1554. [CrossRef] [PubMed]

49. Seidman, A.; Hudis, C.; Pierri, M.K.; Shak, S.; Paton, V.; Ashby, M.; Murphy, M.; Stewart, S.J.; Keefe, D. Cardiac Dysfunction in the Trastuzumab Clinical Trials Experience. J. Clin. Oncol. 2002, 20, 1215-1221. [CrossRef] [PubMed]

50. Hamirani, Y.; Fanous, I.; Kramer, C.M.; Wong, A.; Salerno, M.; Dillon, P. Anthracycline- and trastuzumab-induced cardiotoxicity: A retrospective study. Med. Oncol. 2016, 33, 82. [CrossRef]

51. Ozcelik, C.; Erdmann, B.; Pilz, B.; Wettschureck, N.; Britsch, S.; Hübner, N.; Chien, K.R.; Birchmeier, C.; Garratt, A.N. Conditional mutation of the ErbB2 (HER2) receptor in cardiomyocytes leads to dilated cardiomyopathy. Proc. Natl. Acad. Sci. USA 2002, 99, 8880-8885. [CrossRef]

52. Economopoulou, P.; Kotsakis, A.; Kapiris, I.; Kentepozidis, N. Cancer therapy and cardiovascular risk: Focus on bevacizumab. Cancer Manag. Res. 2015, 7, 133-143. [CrossRef] [PubMed]

53. Yeh, E.T.; Tong, A.T.; Lenihan, D.J.; Yusuf, S.W.; Swafford, J.; Champion, C.; Durand, J.B.; Gibbs, H.; Zafarmand, A.A.; Ewer, M.S. Cardiovascular complications of cancer therapy: Diagnosis, pathogenesis, and management. Circulation 2004, 109, $3122-3131$. [CrossRef] [PubMed]

54. Totzeck, M.; Mincu, R.I.; Rassaf, T. Cardiovascular Adverse Events in Patients With Cancer Treated With Bevacizumab: A Meta-Analysis of More Than 20,000 Patients. J. Am. Heart Assoc. 2017, 6, e006278. [CrossRef] [PubMed]

55. Telli, M.L.; Witteles, R.M.; Fisher, G.A.; Srinivas, S. Cardiotoxicity associated with the cancer therapeutic agent sunitinib malate. Ann. Oncol. 2008, 19, 1613-1618. [CrossRef]

56. Joensuu, H. Cardiac toxicity of sunitinib. Lancet 2007, 370, 1978-1980. [CrossRef]

57. Molina, A.M.; Jia, X.; Feldman, D.R.; Hsieh, J.J.; Ginsberg, M.S.; Velasco, S.; Patil, S.; Motzer, R.J. Long-term response to sunitinib therapy for metastatic renal cell carcinoma. Clin. Genitourin. Cancer 2013, 11, 297-302. [CrossRef] [PubMed]

58. Motzer, R.J.; Hutson, T.E.; Tomczak, P.; Michaelson, M.D.; Bukowski, R.M.; Rixe, O.; Oudard, S.; Negrier, S.; Szczylik, C.; Kim, S.T.; et al. Sunitinib versus interferon alfa in metastatic renal-cell carcinoma. N. Engl. J. Med. 2007, 356, 115-124. [CrossRef]

59. Robert, C.; Ribas, A.; Schachter, J.; Arance, A.; Grob, J.J.; Mortier, L.; Daud, A.; Carlino, M.S.; McNeil, C.M.; Lotem, M.; et al. Pembrolizumab versus ipilimumab in advanced melanoma (KEYNOTE-006): Post-hoc 5-year results from an open-label, multicentre, randomised, controlled, phase 3 study. Lancet Oncol. 2019, 20, 1239-1251. [CrossRef]

60. Moehler, M.H.; Janjigian, Y.Y.; Adenis, A.; Aucoin, J.-S.; Boku, N.; Chau, I.; Cleary, J.M.; Feeney, K.; Franke, F.A.; Mendez, G.A.; et al. CheckMate 649: A randomized, multicenter, open-label, phase III study of nivolumab (NIVO) + ipilimumab (IPI) or nivo + chemotherapy (CTX) versus CTX alone in patients with previously untreated advanced (Adv) gastric (G) or gastroesophageal junction (GEJ) cancer. J. Clin. Oncol. 2018, 36, TPS192. [CrossRef]

61. Gandhi, L.; Rodríguez-Abreu, D.; Gadgeel, S.; Esteban, E.; Felip, E.; De Angelis, F.; Domine, M.; Clingan, P.; Hochmair, M.J.; Powell, S.F.; et al. Pembrolizumab plus Chemotherapy in Metastatic Non-Small-Cell Lung Cancer. N. Engl. J. Med. 2018, 378, 2078-2092. [CrossRef] [PubMed]

62. Konala, V.M.; Adapa, S.; Aronow, W.S. Immune Checkpoint Inhibitors-Related Cardiotoxicity. Am. J. Ther. 2020, 27, e591-e598. [CrossRef] [PubMed]

63. Upadhrasta, S.; Elias, H.; Patel, K.; Zheng, L. Managing cardiotoxicity associated with immune checkpoint inhibitors. Chronic Dis. Transl Med. 2019, 5, 6-14. [CrossRef]

64. Haanen, J.; Carbonnel, F.; Robert, C.; Kerr, K.M.; Peters, S.; Larkin, J.; Jordan, K. Management of toxicities from immunotherapy: ESMO Clinical Practice Guidelines for diagnosis, treatment and follow-up. Ann. Oncol. Off. J. Eur. Soc. Med Oncol. 2017, 28 (Suppl. 4), iv119-iv142. [CrossRef] [PubMed]

65. Johnson, D.B.; Balko, J.M.; Compton, M.L.; Chalkias, S.; Gorham, J.; Xu, Y.; Hicks, M.; Puzanov, I.; Alexander, M.R.; Bloomer, T.L.; et al. Fulminant Myocarditis with Combination Immune Checkpoint Blockade. N. Engl. J. Med. 2016, 375, 1749-1755. [CrossRef]

66. Baban, B.; Liu, J.Y.; Qin, X.; Weintraub, N.L.; Mozaffari, M.S. Upregulation of Programmed Death-1 and Its Ligand in Cardiac Injury Models: Interaction with GADD153. PLoS ONE 2015, 10, e0124059. [CrossRef] [PubMed]

67. Nishimura, H.; Okazaki, T.; Tanaka, Y.; Nakatani, K.; Hara, M.; Matsumori, A.; Sasayama, S.; Mizoguchi, A.; Hiai, H.; Minato, N.; et al. Autoimmune dilated cardiomyopathy in PD-1 receptor-deficient mice. Science 2001, 291, 319-322. [CrossRef]

68. Yang, S.; Asnani, A. Cardiotoxicities associated with immune checkpoint inhibitors. Curr. Probl. Cancer 2018, 42, 422-432. [CrossRef] [PubMed]

69. Menzies, A.M.; Johnson, D.B.; Ramanujam, S.; Atkinson, V.G.; Wong, A.N.M.; Park, J.J.; McQuade, J.L.; Shoushtari, A.N.; Tsai, K.K.; Eroglu, Z.; et al. Anti-PD-1 therapy in patients with advanced melanoma and preexisting autoimmune disorders or major toxicity with ipilimumab. Ann. Oncol. 2017, 28, 368-376. [CrossRef] [PubMed] 
70. Bosch, X.; Rovira, M.; Sitges, M.; Domènech, A.; Ortiz-Pérez, J.T.; de Caralt, T.M.; Morales-Ruiz, M.; Perea, R.J.; Monzó, M.; Esteve, J. Enalapril and carvedilol for preventing chemotherapy-induced left ventricular systolic dysfunction in patients with malignant hemopathies: The OVERCOME trial (preventiOn of left Ventricular dysfunction with Enalapril and caRvedilol in patients submitted to intensive ChemOtherapy for the treatment of Malignant hEmopathies). J. Am. Coll. Cardiol. 2013, 61, 2355-2362. [CrossRef] [PubMed]

71. van Dalen, E.C.; Caron, H.N.; Dickinson, H.O.; Kremer, L.C. Cardioprotective interventions for cancer patients receiving anthracyclines. Cochrane Database Syst. Rev. 2011, 2011, CD003917. [CrossRef] [PubMed]

72. Michel, L.; Rassaf, T.; Totzeck, M. Cardiotoxicity from immune checkpoint inhibitors. Int. J. Cardiol. Heart Vasc. 2019, 25, 100420. [CrossRef]

73. Cardinale, D.; Colombo, A.; Bacchiani, G.; Tedeschi, I.; Meroni, C.A.; Veglia, F.; Civelli, M.; Lamantia, G.; Colombo, N.; Curigliano, G.; et al. Early detection of anthracycline cardiotoxicity and improvement with heart failure therapy. Circulation 2015, 131, 1981-1988. [CrossRef] [PubMed]

74. Cardinale, D.; Colombo, A.; Lamantia, G.; Colombo, N.; Civelli, M.; De Giacomi, G.; Rubino, M.; Veglia, F.; Fiorentini, C.; Cipolla, C.M. Anthracycline-induced cardiomyopathy: Clinical relevance and response to pharmacologic therapy. J. Am. Coll. Cardiol. 2010, 55, 213-220. [CrossRef]

75. Lipshultz, S.E.; Adams, M.J.; Colan, S.D.; Constine, L.S.; Herman, E.H.; Hsu, D.T.; Hudson, M.M.; Kremer, L.C.; Landy, D.C.; Miller, T.L.; et al. Long-term cardiovascular toxicity in children, adolescents, and young adults who receive cancer therapy: Pathophysiology, course, monitoring, management, prevention, and research directions: A scientific statement from the American Heart Association. Circulation 2013, 128, 1927-1995. [CrossRef]

76. Chung, R.; Ghosh, A.K.; Banerjee, A. Cardiotoxicity: Precision medicine with imprecise definitions. Open Heart 2018,5 , e000774. [CrossRef] [PubMed]

77. Ky, B.; Putt, M.; Sawaya, H.; French, B.; Januzzi, J.L., Jr.; Sebag, I.A.; Plana, J.C.; Cohen, V.; Banchs, J.; Carver, J.R.; et al. Early increases in multiple biomarkers predict subsequent cardiotoxicity in patients with breast cancer treated with doxorubicin, taxanes, and trastuzumab. J. Am. Coll. Cardiol. 2014, 63, 809-816. [CrossRef]

78. Armenian, S.H.; Lacchetti, C.; Barac, A.; Carver, J.; Constine, L.S.; Denduluri, N.; Dent, S.; Douglas, P.S.; Durand, J.B.; Ewer, M.; et al. Prevention and Monitoring of Cardiac Dysfunction in Survivors of Adult Cancers: American Society of Clinical Oncology Clinical Practice Guideline. J. Clin. Oncol. 2017, 35, 893-911. [CrossRef] [PubMed]

79. Yoon, H.J.; Kim, K.H.; Kim, J.Y.; Park, H.J.; Cho, J.Y.; Hong, Y.J.; Park, H.W.; Kim, J.H.; Ahn, Y.; Jeong, M.H.; et al. ChemotherapyInduced Left Ventricular Dysfunction in Patients with Breast Cancer. J. Breast Cancer 2016, 19, 402-409. [CrossRef] [PubMed]

80. Narayan, H.K.; French, B.; Khan, A.M.; Plappert, T.; Hyman, D.; Bajulaiye, A.; Domchek, S.; DeMichele, A.; Clark, A.; Matro, J.; et al. Noninvasive Measures of Ventricular-Arterial Coupling and Circumferential Strain Predict Cancer Therapeutics-Related Cardiac Dysfunction. JACC Cardiovasc. Imaging 2016, 9, 1131-1141. [CrossRef] [PubMed]

81. Mousavi, N.; Tan, T.C.; Ali, M.; Halpern, E.F.; Wang, L.; Scherrer-Crosbie, M. Echocardiographic parameters of left ventricular size and function as predictors of symptomatic heart failure in patients with a left ventricular ejection fraction of $50-59 \%$ treated with anthracyclines. Eur. Heart J. Cardiovasc. Imaging 2015, 16, 977-984. [CrossRef]

82. Visscher, H.; Ross, C.J.; Rassekh, S.R.; Barhdadi, A.; Dubé, M.P.; Al-Saloos, H.; Sandor, G.S.; Caron, H.N.; van Dalen, E.C.; Kremer, L.C.; et al. Pharmacogenomic prediction of anthracycline-induced cardiotoxicity in children. J. Clin. Oncol. 2012, 30, 1422-1428. [CrossRef]

83. Yang, X.; Li, G.; Guan, M.; Bapat, A.; Dai, Q.; Zhong, C.; Yang, T.; Luo, C.; An, N.; Liu, W.; et al. Potential Gene Association Studies of Chemotherapy-Induced Cardiotoxicity: A Systematic Review and Meta-Analysis. Front. Cardiovasc. Med. 2021, 8, 651269. [CrossRef]

84. Linschoten, M.; Teske, A.J.; Cramer, M.J.; van der Wall, E.; Asselbergs, F.W. Chemotherapy-Related Cardiac Dysfunction: A Systematic Review of Genetic Variants Modulating Individual Risk. Circ. Genom. Precis Med. 2018, 11, e001753. [CrossRef] [PubMed]

85. Vulsteke, C.; Pfeil, A.M.; Maggen, C.; Schwenkglenks, M.; Pettengell, R.; Szucs, T.D.; Lambrechts, D.; Dieudonné, A.S.; Hatse, S.; Neven, P.; et al. Clinical and genetic risk factors for epirubicin-induced cardiac toxicity in early breast cancer patients. Breast Cancer Res. Treat 2015, 152, 67-76. [CrossRef]

86. Hébert, H.L.; Shepherd, B.; Milburn, K.; Veluchamy, A.; Meng, W.; Carr, F.; Donnelly, L.A.; Tavendale, R.; Leese, G.; Colhoun, H.M.; et al. Cohort Profile: Genetics of Diabetes Audit and Research in Tayside Scotland (GoDARTS). Int. J. Epidemiol. 2018, 47, 380-381j. [CrossRef] [PubMed]

87. Pinheiro, E.A.; Magdy, T.; Burridge, P.W. Human In Vitro Models for Assessing the Genomic Basis of Chemotherapy-Induced Cardiovascular Toxicity. J. Cardiovasc. Transl. Res. 2020, 13, 377-389. [CrossRef] [PubMed]

88. Lam, C.K.; Wu, J.C. Clinical Trial in a Dish. Arterioscler. Thromb. Vasc. Biol. 2021, 41, 1019-1031. [CrossRef] 